\title{
From Performance to Performativity: The Christchurch Mosque Murders and What Came After
}

Time, arrested by trauma, unwinds toward interpretation. (Nichols 2007:95) ${ }^{1}$

On Friday $15^{\text {th }}$ March 2019, a white Australian man armed with assault weapons attacked Muslim worshippers at two mosques in Christchurch, New Zealand. $^{2}$ Fifty-one people were murdered. Another 49 were injured. Families and their communities were devastated. Almost a year later, they are evermore deeply into the hard, impossibly sad process of recovery. The city of Christchurch, still reeling from the catastrophic earthquakes of 2010-2011, took the blow to its determinedly imperturbable façade hard, but is now moving on. Aotearoa New Zealand likewise.

Staged as a series of performances, the attack and its aftermath were also acutely performative. The gunman transmitted the images and sounds of his whitesupremacist-fuelled, assault-weaponized violence via

\footnotetext{
${ }^{1}$ The present article builds on a paper originally produced for the Pacific Publics: Transpacific Performance working group at ASTR (2019). My thanks to Natascha Diaz-Cardona and Mihailo Ladevac for their feedback on an early draft of this paper, to Teena Brown-Pulu and Richard Pamatatau for their encouragement, and to Paul Moon and Melissa Derby for their support in seeing it through to publication.

2 Media coverage of this event has been extensive both nationally and internationally. In general, I will not cite specific sources unless it seems necessary and/or useful. Following the lead of our Prime Minister, I will not name the gunman here.
}

Sharon Mazer is Professor in Theatre \& Performance Studies at Auckland University of Technology. 
livestream on Facebook: himself the protagonist, his victims the unwitting antagonists in a filmed performance for an unseen audience. In response, Prime Minister Jacinda Ardern immediately took centre-stage: meeting the media, comforting the victims, commending the first responders, and leading two commemorative events on public platforms set up in the park across from Masjid Al Noor, the primary target. For the first, on $22^{\text {nd }}$ March, Ardern wore a hijab as a sign of respect, inspiring thousands of imitators wanting to perform their solidarity with Muslim women; for the second, on 29th March, she donned a korowai (feathered cloak) in keeping with the Māori protocols that framed the event. There were other, more ad hoc, performances, too, including haka (ritual chant/dance) by school groups, gang members and other odd individuals in front of Masjid Al Noor. Almost immediately after the mosque murders, plans for films, television specials and serials, and theatre performances began proliferating exponentially.

Ardern's performances were hailed nationally and internationally as exemplary. Her declaration that "this is not us" disidentified New Zealanders from the Australian terrorist, as did her counter-assertion that "they are us." While idealistic, neither claim was entirely reassuring given the history here. The well-intentioned re-imagining of a multicultural Aotearoa, of an "us" (the predominantly white, presumptively New Zealand born majority) embracing a "them" (a predominantly Muslim, presumptively immigrant minority) reified rather than belied the binary configuration in ways that were complicated by New Zealand's status as a bicultural nation: an "us" composed of Māori as well as Pākehā. ${ }^{3}$ As a speech-act, it implied the reverse could be as easily effected: "they" might not be "us" after all. This essay

\footnotetext{
${ }^{3}$ Māori are the Indigenous people of Aotearoa; Pākehā is the word commonly used to refer to non-native New Zealanders, in particular the descendants of the original British settlers.
} 
reflects on questions of performance and performativity in the wake of the mosque murders.

\section{Christchurch is a far place}

By all accounts, the gunman came to New Zealand from Australia, first to train in obscurity and then to stage his murder for maximum effect. Why Christchurch? A small city on New Zealand's South Island, Christchurch is still in recovery from the massively destructive earthquakes of 2010 and 2011 (see Mazer 2013; 2015). It is otherwise perhaps most widely known for being the site of the Parker-Hulme murders in 1954, made famous again as the subject of Peter Jackson's film Heavenly Creatures (1994). Before the earthquakes, Christchurch was best described, I think, as "a city flat as conformity" (Hood 2001:115). It certainly seemed complacent enough when I arrived in 1994; still fond of its colonial origins, its citizens called it "more English than the English" without any discernible irony - at least none that I could hear with my American immigrant's ear. Arriving to take up a position at the University of Canterbury in 1994, my initial impression was "Portland, Oregon, twenty years ago" - a description that, earthquakes aside, still holds: dominant white culture, teeming hippy-esque subculture, a loose alliance of progressive activists counterweighted by a virulent strand of white supremacism, and largely invisible communities of colour themselves the legacy of a history of racial exclusion. ${ }^{4}$

From the outside, it seemed the Muslim community, like the city's other minority groups, like the Jewish community to which I belonged, did well to keep under the radar. The mosque on Deans Avenue was visible; but sited opposite to the playing fields of Hagley Park, before the attack it was easy enough to overlook, especially in the crush of families competing for parking

\footnotetext{
${ }^{4}$ For a view of how Christchurch represents its demographics, see the Christchurch City Council and Healthy Christchurch (Waka Toa Ora) websites.
} 
Saturday mornings. Women in hijab, niqāb or burka might be seen shopping at the mall; men in taqiyah and shalwar kameez too. But Christchurch society tends to avert its eyes from signs of difference. Denial of otherness is only proper, I've been told. It's a key tenet of tolerance, although the question of who is tolerant and who tolerated is one of power and ambivalence in my experience.

Describing her encounters with polite Germans as a Jewish person in 1980s Berlin, Susan Neiman observes, with some amusement, that Germans "were raised with the notion that Jewishness is something unpleasant, and probably smelly, so that noticing it would be like a sign of bad manners. Like white Americans proudly asserting that they do not notice color, they fail to notice the history of assumptions behind that claim" (2019, italics in original). So too the upright citizens of Christchurch. The little flutter, the flicker of fear of a faux-pas, the over-compensatory notso-funny joke or the white-tissue-papery aged hand of a Friend of Israel clutching mine too closely while tremulously confiding "and then it came to me, if I'd been Jewish, I might have died in Auschwitz too" . . .

In comparison to the Muslim community, the Jewish community in Christchurch is miniscule, about 70 families. Had the gunman targeted our synagogue, on the other side of the park, at the start of services later that day, he would have been hard-pressed to find a minyan - assuming he could have breached the high metal fence installed and security company hired after repeated threats against our community. ${ }^{5}$ Still, I cannot help imagining the handful of observant Jews, the weekly mix of locals and visitors relishing the grace of our shul and each other's company, so violently violated. Even

\footnotetext{
${ }^{5}$ Such measures are not so reassuring as they might seem. Arriving for services, holding my young daughter's hand while walking through the gate, past the (non-Jewish) guards made us feel exposed, marked as a "them" to their "us" - a reminder, too, that we were potential victims.
} 
now, having moved from Christchurch to Auckland five years ago, I see myself in their midst.

By all accounts, including his own, the gunman's decision to target Christchurch's small, almost invisible Islamic community was performative. He was calculating impact, courting notoriety, promoting himself. New Zealand is not like the USA, where gun violence is so commonplace and mass murder so much a daily occurrence that it's a struggle to hold the spotlight for more than a single news cycle. The very unlikelihood of Christchurch being the site of mass murder, its reputation for being a placid sort of place where nothing of interest (earthquakes aside) ever happens, would serve to heighten its dramatic effect. The livestreaming extended the gunman's reach beyond the local; its innovative use of technology and social media assured him a place in the history books and has made him a role model for like-minded gunman in a perverse competition for the world's attention. ${ }^{6}$

\section{Performing mass murder}

It's fairly easy to step into the gunman's dramaturgical and theatrical imaginary. The setting: a balmy garden city, basking in the afterglow of summer, the sharp angles of incipient autumn. (Truly the light through the trees in Hagley Park, as seen from the sidewalk in front of the mosque, can be extraordinarily beautiful in March.) The time: early afternoon Friday, when the work week is winding down. The city's small Muslim community is gathering for prayers. There's an odd quiet, a lull before the evening rush. The protagonist is snapping selfies in advance; dressed for combat, his military-style weapon decorated with white nationalist symbols, he is also equipped with a Go-Pro (or something like it) for filming on the run, like the Navy Seals who

\footnotetext{
${ }^{6}$ Subsequent attacks including those aimed at Jewish worshippers in Poway, California (27 April 2019) and at Latinos in El Paso, Texas (3 August 2019) have cited the Christchurch gunman and his manifesto as sources of inspiration.
} 
attacked Bin Laden, or a video-game avatar. ${ }^{7}$ The antagonists are diverse but, to his eyes, undifferentiated men and women of colour in mystifying variations on Islamic garb, talking unintelligibly as they mill about outside, kneeling and keening inside.

The scene begins when he steps out of his car, musters his gear, surveys the terrain, and takes his first steps toward the mosque. The action has its own momentum, an adrenalized inevitability as the automatic weapon takes over and the bodies fall. There are no spectators in the space of performance itself, only online, in the gunman's imagination, even as he rushes back to his car and races from Masjid Al Noor to the next site of performance. Did he have a script for when Abdul Aziz hit him with an EFTPOS machine and chased him away from the Linwood Mosque? Did his script include his death, struck down by a hail of bullets (as the cliché goes), a martyr to his cause? Or was his capture - cornered by two police officers, tackled and manacled in the street (filmed by an onlooker) - part of the scenario, a different kind of martyrdom, perhaps, but in still standing, still heroic? Had he reckoned on the horrible actuality, the sight, sound, smell, the viscera of people - men, women and children (such small children) - struck, bleeding, dying, pleading, crying . . . or was the reality of his encounter with the humanity of his targets superseded by the show unreeling in his head, its images and sounds?

The gunman's actions were almost immediately rendered obscene: performed to be seen but pushed out of sight with a prohibition against looking. 8 The Prime

\footnotetext{
${ }^{7}$ Referring to the Muslim perpetrators of 9/11, Bill Nichols notes: "The terrorist event [. . .] deploys a technology of destructive concentration: Promethean martyrs to a belief beg, borrow or steal the power of modern technology from its creators to maximize the catastrophic event" (2006:101). That in this instance, almost twenty years on, the terrorist was a white nationalist makes the image of a "Promethean martyr" even more striking.

8 Reports have been that the manifesto and the film continue to circulate, for the most part under the radar.
} 
Minister refuses to speak his name or countenance his image; although the suppression of both has been formally lifted, for the most part the media have respected the injunction. It is illegal to download and distribute the manifesto and the film, although both are in circulation, and several people have been arrested and charged. The gunman has been prohibited from producing public statements; although a couple of letters have evaded the prison's censor, this silencing has been effectively enforced. The Prime Minister's logic has been to deny the gunman the value of his performance as he appears to have imagined it. Her own performances in the weeks following were staged both as rebuke and as a way of reclaiming the stage.

\section{From performance to performativity}

The image endures: New Zealand's Prime Minister, Jacinda Ardern, her dark hair covered by a gold-trimmed black scarf, eyes closed as she embraces a female survivor in Christchurch the day after the event. Profoundly moving, the photograph circulated the globe and was even, for a time, projected onto a building in the UAE. From the moment she stepped out of the blackcurtained darkness into the light of her first postmassacre press conference, Ardern's performance was deliberately, if somewhat contradictorily, counterperformative: "this is not us," "they are us." With her repeated refusal to speak the gunman's name, to countenance his image or to engage with his manifesto and film, she did her best to manoeuvre the spotlight away from the horror show and onto her representation of an idealized, inclusive New Zealand.

Ardern held two press conferences on March $15^{\text {th }}$. Looking now, it's possible to see her performances evolving in real time: from shocked, but poised improvisation immediately following the event to something more consciously prepared and constrained a 
few hours later. ${ }^{9}$ For the first, she appears at a table. Wearing a dark blazer over a reddish top, she leans slightly forward toward the microphone. Her hands graze the sides of a piece of paper that looks to have been folded in eighths. We learn later that it holds the very few notes she scribbled just before her entry, including the nowiconic phrase "they are us" (NZ Herald 2019d). She begins with a figurative embrace of the victims, one that would be followed by many actual hugs over the days that followed:

Many of those who will have been directly affected by this shooting will be migrants, they will be refugees here. They have chosen to make New Zealand their home and it is their home. They are us.

And then a repudiation of the murderer:

The person who has perpetuated this violence against us is not. They have no place in New Zealand. There is no place in New Zealand for such acts of extreme and unprecedented violence which it is clear this act was.

The pronouns tend to slip. "They" are the Muslim people, identified primarily as migrants and refugees, those who live here without having been born here; "they" is also the unidentified perpetrator. The "us" stays more constant: the not-Muslims who, even so, are hereby instructed to see the Muslim victims in our image and, just as importantly, to refuse identification with the gunman. In fact, it seems the inclusion of the former cannot be effected without the exclusion of the latter.

In thus (re)imagining the New Zealand community, Ardern pitched her multi-cultural vision of New Zealand as a nation against the white nationalism of the gunman. The two world views are not so far apart, perhaps, as they might seem. In Imagined Communities, Benedict Anderson critiques the nationalist imperative for the way

\footnotetext{
${ }^{9}$ See the coverage on the RNZ (Radio New Zealand) website, which contains video clips of both press conferences (2019a). The texts of the Prime Minister's speeches have been taken from these clips.
} 
it is "imagined as a community, because regardless of the actual inequality and exploitation that may prevail in each, the nation is always conceived as a deep, horizontal comradeship" (2006:7, italics in original). While eschewing the tiresome American trope of "thoughts and prayers', Ardern nonetheless invoked a kind of secular sacred, a fall from grace in "Godzone" (as New Zealand is sometimes called ${ }^{10}$ ). Anderson sees the problem of nationalism arising from the Enlightenment: "Disintegration of paradise: nothing makes fatality more arbitrary" (2006:11). Nationalism, in Anderson's formulation, effects "a secular transformation of fatality into continuity, contingency into meaning" (2006:11). For the most part, for a while at least, we who are not Muslim New Zealanders agreed both to be and to include them in the "us" that Ardern so generously imagined.

This was not as easy as it sounds. After watching the Prime Minister's first press conference on the computer in my office, I made my way home. It was impossible to concentrate; I was upset and transfixed by the news as it unfolded. My Saudi Arabian neighbour from across the hall, whom I rarely encountered, entered the lift as I did. She was covered head to toe in her usual beige and black niqāb, her beautifully made-up eyes making contact as we greeted each other and then fell silent. It's a short ride up. My mind raced in slow motion. What to say? The drama was still being reported. She might not even know, I thought, and I'm ill-equipped to be the bearer of such news. And so we remained, cordial and distant. Her lease came up a month or so later, and she moved away. What were the chances that we would meet in that way on that day? Should I have said something? What could I have said? I still don't know. We were so close. But we weren't close enough. She was my neighbour. I recognized her as a stranger - in Sara Ahmed's words, "a figure that is painfully familiar in that

\footnotetext{
10 "Godzone" is an evolution of the $19^{\text {th }}$ century designation: "God's Own Country" (Thornbar 2018).
} 
very strange(r)ness" (2000:21) - as perhaps she did me. The attack on the mosques in Christchurch, on people like her, watched by people like me, engendered in me a sense of intimacy, no less compelling for being imagined rather than real. She was visible to me, not quite a victim, but not quite not a victim either.

The Prime Minister's second press conference was more conventional in some ways. She stood at a podium; a row of brightly coloured New Zealand flags - the red stripes picking up and refracting the colour of her top was set against the black curtained backdrop. The scenario is starting to come into focus, she tells us: the gunman's nationality, Australian; his views, white supremacist - views, that in Ardern's words, "have no place in New Zealand, in fact, no place in the world"; his actions, terrorism; the threat level, high. The police are onto it, the investigations just beginning. She will soon speak to the mayor of Christchurch and to the imam of Masjid Al Noor. She has a message that she is "sure all New Zealanders" would like her to share:

Our thoughts and our prayers are with those who have been impacted today. Christchurch was the home of these victims. For many, New Zealand was not the place they were born, in fact for many New Zealand was their choice. It was the place they committed themselves to, where they were raising their families, where they were part of communities that they loved and who loved them. It was a place that many came to for its safety, a place where they were free to practice their culture and their religion. We, New Zealanders, need to know this about them, who are mostly not.

For those of you who are watching at home tonight and questioning how this could have happened here, we, New Zealand, we are not a target because we are a safe harbour for those who hate, we were not chosen for this violence because we condone racism, because we are an enclave for extremism, we were chosen for the fact we represent none of 
these things. Because we represent diversity, kindness, compassion, a home for those who share our values, refuge for those who need it.

We, New Zealanders, need to know this about ourselves. We are not like him, the Australian.

And those values, I can assure you, will not and cannot be shaken by this attack. We are a proud nation of more than 200 ethnicities, 160 languages and amongst that diversity we share common values and the one that we place the currency on right now and tonight is our compassion and the support for the community of those directly affected by this tragedy.

We, New Zealanders, contain multitudes, including them ...

Secondly, the strongest possible condemnation of the ideology for those who did this ... we utterly reject and condemn you.

... and excepting him, the Australian. With this meeting of the press, broadcast nationally and transmitted around the world, the Prime Minister set aside the image of bicultural Aotearoa to imagine a multicultural New Zealand. The violence was a violation of the national ethos by an intruder from outside. This was not us. Or is it?

When the news broke, I immediately messaged my daughter, who was completing a postgraduate degree in Chicago. Her response was rage, and an almost instantaneous Instagram post. She pulled it down after an hour or so, but the sentiment stuck. Born ten months after her father and I arrived in Christchurch, she is at once a proper Kiwi and an outsider. The mosque murders opened a floodgate: the countless small and large humiliations of her strange, estranged experience as the only Jewish child in her (public) primary school - made to sit in the library while her classmates undertook their weekly Bible lessons - and as one of two Jewish students in her (private) Anglican secondary school. She remembers, as I do, the time white nationalists took over 
Cathedral Square on a Saturday morning to protest against the presence of Asians in the city. She was in class then, with her Singaporean art teacher, both torn between anger and fear. Christchurch seemed rather fond of Kyle Chapman, the leader of that march: he might be a white nationalist, but he's our white nationalist. ${ }^{11}$ Christchurch's benevolence was seen as a sign of the city's tolerance, its willingness to indulge such eccentricities, to chuckle, casually titillated, at expressions of white racism. But in truth, whether amongst the parents at my daughter's schools or in the Canterbury University Staff Club, many of the good middle-class Cantabrians of my acquaintance were inclined toward genteel expressions of similar sentiments.

\section{Tolerance, identification, compassion . . . alibi?}

Ardern's poised performance at the podium as a Prime Minister fronting up to a national crisis was widely praised. ${ }^{12}$ Even more exemplary were her appearances thereafter as she travelled multiple times to Christchurch to meet first responders and city leaders, and to comfort survivors. Comparisons continue to be drawn, inevitably, to the current Commander in Chief of the USA, ${ }^{13}$ whose opportunities to step up after mass shootings have proliferated in recent months in a perverse cycle of inspiration: both shooters and politicians now appear to be constructing their actions and images with Christchurch in mind.

\footnotetext{
${ }^{11}$ Chapman appears to have settled down in recent years, and he has disavowed any connection to the Australian gunman, but they're of a piece.

12 Time magazine has just put Ardern on its cover with a story titled:

"A Year After Christchurch, Jacinda Ardern Has the World's Attention. How Will She Use it?" (Luscombe 2020).

13 Witness the widely circulated, and derided, image of Trump giving a cheery thumbs-up, standing next to two of the El Paso survivors and Melania, who is smiling as she holds a newly orphaned baby on display for the camera (Helmore 2019).
} 
The country, and the world, swooned when, landing in Christchurch the day after the massacre, Ardern wore a scarf, hijab-style, to meet survivors and community leaders (see, for example, Malik 2019). This seemed like an unremarkable gesture of respect for the spaces she was entering, for the people she was meeting - equivalent to the way a man, Jewish or not, observant or not, coming into a synagogue would be expected to cover his head, equivalent to the expectation, in Aotearoa New Zealand, that shoes are removed before entering a wharenui (meeting house). The (over)reaction to Ardern's courtesy was due, in part, to the ready comparison with leaders in other countries, the USA in particular, and also to the powerful way photographers captured her solemnity and empathy. The images quickly de-contextualized and took on a life of their own, amplified by the press and by social media to a high pitch. Security expert Paul Buchanan, whose televised appearances pointedly criticized the government for ignoring the terror threat posed by white supremacists, seeing Muslims only as possible perpetrators rather than potential victims, said that Ardern was "like the mother of the nation" (qtd in Roy 2019).

Within days, the scarf was wrapped around Ardern's central message: "they are us." It came to signal sympathetic identification more than respect for religious custom. Stories of harassment before, during and after the shooting surfaced in the media: of abuse hurled at Muslim women marked as targets by hijab, niqāb and burka (see, for example, Russell 2019). None of this was new, but it became news. Horror at the mosque murders, a singular event in New Zealand history, was refracted into shock at hearing of the more ordinary nastiness to which our Muslim neighbours are regularly subjected. What could we do, beyond not being so mean ourselves, beyond laying flowers, cards and other tributes along the designated fence?

Ardern had worn the hijab, in part she said, "to show solidarity with those most visible and hence most 
vulnerable to attack" and to give "them a sense of security to continue to practice their faith" (qtd in Malik 2019). Women across New Zealand almost immediately put on scarves themselves, began to organize on social media and one week after the attack, on Friday $22^{\text {nd }}$ March, staged a 'Headscarf for Harmony' day (also called 'Scarves in Solidarity'). There is something in this of the "condescending and depressive power of good intentions, a power that can dream of nothing except rectitude in the world" (Baudrillard 1993:86). These well-meaning women were not unlike my high school drama class, who donned gold stars for a week or two while rehearsing a production of The Diary of Anne Frank - an odd performance of identification, a scant 26 years after the Holocaust, in a place (rural Oregon) that, beyond my own family, was Jew-free. Wearing scarves as hijabs almost 50 years later in New Zealand, they are not so far removed from the high-schoolers we were in wishing to enact our sympathies so sartorially.

In "The Violence of 'We': Politicizing Identification," Elin Diamond follows Hélène Cixous in discussing "the mimetic pleasure of identification - becoming or inhabiting the other on stage or in spectatorial fantasy, I stand in for her, act in his place" (1992:390). "Such acts," Diamond says, "are distinctly imperialistic and narcissistic: I lose nothing - there is no loss of self - rather I appropriate you, amplifying my 'I' into an authoritative 'we" (1992:390). Diamond's focus is mimetic realism in the theatre, not performativity in everyday life. Even so, her reminder that because it "bridges the psychic and the social, identification has political effects" (1992:391) offers a cautionary note about how acts of identification too often potentially enact reification in service of the dominant culture.

Wearing scarves hijab-style to demonstrate indifference to difference, leaving flowers as tribute to the victims of violence on a memorial wall, seeking out and hugging Muslim people at services and, even, in chance encounters on the sidewalk to make an "us" out of a 
"they" and "we" - this is what good people do when bad things happen. It's a performance of empathy, of compassion. But compassion, like identification, like tolerance, is more ambivalent than it seems: a powerlaced imbrication of social relations that maintains, rather than challenges, the status quo. In her introduction to Compassion: The Culture and Politics of Emotion, Lauren Berlant tells us that compassion "is a term denoting privilege: the sufferer is over there (2004:4, italics in original). For Berlant, "The Freudian notion of Schadenfreude, the pleasure one takes in the pain of another, only begins to tell the unfinished story of the modern incitement to feel compassionately - even while being entertained" (2004:5). Compassion has its performative conventions; those of us who have not been directly in the firing line, become spectators to "theatrical scene[s] of suffering" (2004:6) who can be seen to stage "scenes of compassion" (2004:6). As such, "Compassion turns out not to be so effective or a good in itself" (2004:9). Rather: "The modern social logic of compassion can as easily provide an alibi for an ethical or political betrayal as it can initiate a circuit of practical relief" (2004:11). Like tolerance, like identification, compassion constructs ideas of communality and belonging that often as not serve the dominant culture even as it appears to redress schismatic events.

In the epic final volume of Karl Ove Knausgaard's My Struggle, the author pauses his lengthy disquisition on Hitler's Mein Kampf to muse on his response to the mass murder of 71 people, most of them teenagers, by a white nationalist in Norway:

What I felt was the pull of the we I knew, the pull of belonging, of being a part of what is good and meaningful. More democracy, greater openness, more love. This is what Norwegian politicians said, it was what the Norwegian people said, it was what I said to myself as I sat and wept and watched it on TV, the pull it exerted on the emotions was so strong, and the feelings I felt were real and 
authentic, they came from the heart: this had happened at home, and those gathering in the streets were my people. (2018:811)

Being supremely self-aware and self-critical, or at least performatively so, he immediately steps back:

Now that I am removed from them I have difficulty grasping those feelings. They seem false, induced only by the power of suggestion. I knew none of the dead, how could I grieve for them as I did? How could I feel such a strong sense of belonging? And yet the feelings were quite incontestable, and swept everything else aside during the time of the tragedy. (2018:811)

And as if it weren't sufficiently heretical to open himself to the possibility that his grievous response might have been induced as part of the public mourning for his country's innocents/innocence, he slides away from the present moment back into his Holocaust-centred reverie:

Only afterwards did I realise that these must have been the same forces, the enormous forces that reside within the we, that came over the German people in the 1930s. That was how good it must have felt, how secure the identity they were being offered must have appeared to them. The flags and banners, the torches, the demonstrations: that was what it must have been like. (2018:811)

In this radical act of empathetic slippage, he discovers how he might have found himself on the wrong side of history: "Against this we stood the they of the Jews" (2018:811, italics in original). He's not defending the Germans or denying the Holocaust. He's considering how he might have been one of the mob.

As Amin Maalouf observes, in In the Name of Identity: Violence and the Need to Belong: "There is a Mr. Hyde in each one of us" (2012:28). He goes on:

The fact is, it's difficult to say where legitimate affirmation of identity ends and encroachment on the rights of others begins. Did I not say that the word identity was a "false friend"? It starts by 
reflecting a perfectly permissible aspiration, then before we know where we are it has become an instrument of war. The transition from one meaning to the other is imperceptible, almost natural, and sometimes we all just go along with it. We are denouncing an injustice, we are defending the rights of a suffering people - then the next day we find ourselves accomplices in a massacre. (2012:32-33)

Where Knausgaard sees himself slipping on the surface of a white nationalism that he finds too close to home, Maalouf takes us on a tour of violence in the name of identity around the world - Lebanon, Rwanda, South Africa - to demonstrate how quickly a "we" can splinter into "us" versus "them" as identification with/as victims comes to alibi atrocity.

\section{New Zealand, racist as . . . ?}

Headscarf-wearing women aside, within days, the constructed image of New Zealand as a peacefully diverse, non-racist community quickly came under fire. The prominent historian, Dame Anne Salmond issued a blistering rebuke in an opinion piece for the $N Z$ Herald. Titled "Racist underbelly seethes just beneath surface" her essay leads with

After this terrible tragedy, let's be honest, for once. White supremacy is a part of us, a dark power in the land. In its soft version, it looks bland and reasonable. Eminent New Zealanders assure their fellows that Māori were "lucky" to be colonised by Europeans, that te reo Māori is worthless, that tikanga Māori have nothing to teach us. (Salmond 2019)

She goes on

In its hard version, it's violent and hateful, spewing out curses, incarcerating young Māori in large numbers, denying them a decent education, homes and jobs, telling them they have no future and are better off dead. 
And on

After Māori, the indigenous people of this country, this sense of white superiority spills out over "other" groups - Pasifika, Asian people, and now Muslims in Christchurch.

For Salmond, "white supremacy is a black strand woven through our history as a nation." She briskly works her way through the history of colonization. While praising the Prime Minister for taking "a stand for kindness and generosity, aroha and manaakitanga in the relations among different groups in our country," she reminds readers that Muslims "are not the only group who are targeted by white supremacists, and there are more ways of killing and maiming people than with a gun."

No less fiercely alert to the white supremacist inclinations of the dominant culture here, Samoan-born New Zealand theatre artist Oscar Kightley, observes "This may or may not be us, but they certainly walk among us," adding: "Perhaps part of the reason those in custody didn't appear on any security watch lists is because of the sheer volume of people with the same views. You can't see the wood for the trees" (Kightley 2019). Salmond and Kightley weren't saying anything new. A year before the mosque murders, prominent filmmaker Taika Waititi had sparked outrage by saying that "New Zealand is racist as fuck." His statement captures the ambivalence that many of us who are not descended from British settlers feel here: "I think New Zealand is the best place on the planet, but it's a racist place" (qtd in 1news 2018). ${ }^{14}$

\section{"Us" mourning}

A stage was set up across the road from Masjid Al Noor in North Hagley Park. The site of annual celebrations like Christmas in the Park and Sparks in the Park, this time the platform was given over to collective acts of mourning. The first service was led by Imam

\footnotetext{
${ }^{14}$ Waititi's anti-racism public service announcement is itself a masterpiece of counter-performativity. See: "Give Nothing To Racism" (NZ Human Rights Commission 2017).
} 
Gamal Fouda, himself a survivor of the attack, with the Prime Minister in attendance, and timed to align with the Friday call to prayer exactly one week after the massacre on 22 March. It was broadcast live, with similar events staged in cities across the country. The call to prayer was followed by a moment of silence. There were prayers, and a heartrending speech by Fouda: "We are brokenhearted, but we are not broken. We are alive, we are together, we are determined not to let anyone divide us" (RNZ 2019b). Fouda's "we" and his "us" glide around Ardern's "they" and her "us": at once referring to the survivors of the attack, the Muslim community and all of New Zealand.

With the service in the park, the filmed performance that the gunman sought to transmit worldwide was supplanted by another livestreamed film. The Muslim community was still the object. They were planted front and centre, their prayer mats on the grass, in segregated men's and women's areas. Set apart from everyone else by low fencing as they observed their rituals, kneeling and bowing together, they were themselves observed by an audience of non-Muslims both in the park and via the livestream. With the cameras held in non-Muslim hands, the intimacy of worship gave way to performative display of "them" and "us": the siting/sighting of Muslims at the heart of the wider community; the surrounding of the victims by those who were not in a kind of collective embrace.

The second event, exactly a week later, was a "National Remembrance Service." It was again timed to coincide with that of the attack. Representatives from 59 countries, including Australia's Prime Minister, were in attendance, and there were musical performances by Yusef Islam (formerly Cat Stevens) and an array of New Zealand performing artists. The staging of mourning and memorialization seemed already to be moving from the sacred to the secular, and more overtly to what might be described as nationalism in a transnationalist frame (NZ Herald 2019c). The featured speaker was Farid Ahmed, a 
survivor whose wife died in the attack. Sitting in his wheelchair, a sign-language interpreter at his side, he spoke of mercy and faith, chanted and prayed. The concert followed. This time there were chairs, for the dignitaries as well as victims in the VIP section at centre, the re-configured heart of the ceremony. The Prime Minister again addressed the public, this time wearing a korowai (feathered cloak) in keeping with the more visible participation of Māori leaders. Also visible, again, were the police, screening people as they entered, patrolling with sniffer dogs, a reassurance of safety and a reminder of the danger - a lingering frisson, perhaps, of "they are us."

In "The terrorist event," Bill Nichols observes: "There is no satisfactory meaning to a traumatic event; this is what makes it traumatic. Bestowing form enacts a misrecognition of the fundamental nature of the experience itself [. . .]" (2007:97). Nichols is writing about 9/11 and the "mass-mediated government framing of the event that has minimalised mourning and forestalled melancholia by its insistence on a righteous, crusading triumphalism against a barbarous axis of evil" (2007:99). Almost twenty years on, in New Zealand, Prime Minister Ardern can be seen to have tweaked the Bush administration's playbook somewhat with repeated acts of large-scale mourning on national platforms giving way to aggressive enactment of gun control legislation. ${ }^{15}$

Vesting the gunman with responsibility for the evil act and isolating him from public view offered "us" a swift and relatively satisfying performance of redress - or at least its promise with the trial forthcoming. But the victims - the "they" who are "us" - have also largely been removed from view as they continue to confront the challenges of recovery. As the first anniversary of the

\footnotetext{
15 Ardern was lauded internationally for pushing through new arms control laws within days of the murders. As of this writing, the period for voluntary surrender of semi-automatic weapons and components has closed with over 60,000 now-prohibited firearms having been removed from circulation, according to the government (Nash 2019).
} 
murders approaches the rest of "us" appear to have settled back into an approximation of the status quo ante, as if attaining the final stage of Turnerian Social Drama were inevitable instead of open to question. The potential rent in the seam of New Zealand's self-regard has been re-sutured with remarkable alacrity. Where the USA remains essentially, existentially at war with the Muslim world twenty years on, New Zealand is apparently again at peace with itself and the world.

\section{Performing Artists}

It took more than a week for the victims to be formally identified and released for burial. In less than that time, theatre and film makers were already beginning to talk about what they might make of the murders. Perhaps this was to be expected. From the outset, the experience had been saturated with performance and performativity: everyone reacting and acting, watching, and being in some way watched. The gunman had seen himself performing, making his horror show into a film for instantaneous viewing. The Prime Minister had, necessarily, refashioned herself as she progressed from one public performance to the next. NonMuslim women had posted videos of themselves wearing scarves and hugging Muslim women on social media. The services in Hagley Park were huge spectator events, mirrored by vigils in other New Zealand cities, and broadcast both formally and informally, recorded on cell phones, circulated via social media and reported on widely. ${ }^{16}$ Victims were eloquent in interviews and on platforms; their voices given to us as testament to their injuries and resilience, even before the full extent of the damage and what it might take to move forward toward some as-yet not quite imaginable new status quo was known.

\footnotetext{
16 These include a moving hour-long performance in tribute to the victims staged by the predominantly Māori and Pacific community at my university livestreamed on Facebook (Pacific at AUT 2019).
} 
What then could an artist do? And why? Why imagine making a film, or a limited television series, or a documentary theatre performance - all ideas floated within days of the shooting - when the real thing is still playing out in front of us? When the bodies have not yet been released for burial? When the mourning is just starting to take hold? At what point in time - a month, six months, a year - does it become appropriate to turn an atrocity into art, to tell a story that isn't necessarily ours to tell? How can we not make art that looks like a scarf that has been pressed into service as a hijab or a paper cut-out yarmulke (The Associated Press 2018; Connolly 2019) - a display of earnest empathy that keeps the wearer in the spotlight and the people whose story this is in the shadows? ${ }^{17}$

That theatre and performance artists, as well as film and television makers, felt urgent about putting their creativity to use in support of the victims in Christchurch was an understandable, even commendable, component of the desire to make sense of the violence, to reassert some semblance of rightness in the public eye. They wanted to do more than to leave flowers on the memorial wall on Rolleston Avenue, to bake casseroles, scones and muffins, or to undertake other such homely but useful expressions of sympathy. They wanted to act for the victims while also taking a stand against white nationalism - to invoke the power of performance to enact redress. At the same time that they were drawn towards the drama of the tragedy, most (but not all) also recognized the risks of being seen to capitalise on the pain of others and as such many could be seen to be afflicted with almost anti-theatrical fastidiousness - hearing perhaps the axiomatic echo of Adorno's adage that to "write poetry after Auschwitz is barbaric" (see Dabashi 2014).

\footnotetext{
${ }_{17}$ My concern for the artist/subject relationship in documentary theatre here is not so removed from the problem of performance ethnography as I have previously explored (Mazer 2011).
} 
In this, most of these first theatrical responders reflexively turned toward the documentary form, following what are now well-established models: Anna Deavere Smith's Fires in the Mirror and Twilight: Los Angeles, and Moises Kaufman's Laramie Project in the USA; Miranda Harcourt's Verbatim in New Zealand. For them, the virtue of the documentary approach is that it represents a turn away from "acting" in the sense of "pretending" (see Schechner 1993). To speak both with and for the victims in this way conflates humility with facticity. Instead of making a play per se and casting themselves in starring roles, these artists see themselves rejecting an almost reflexive desire for the relative comfort of a dramaturgical "real" of the sort critiqued by Elin Diamond in "The Violence of "We" (1992), instead performing radical empathy and enacting utopian performativity (see Dolan 2005).

There is, in the discussions I've overheard, a fervent faith in the redemptive power of the theatre. There is also a certain narcissism at work here, a transference of the ego-centric drive to stardom into an idealized vision of the self as shaman or exorcist on terms Richard Schechner outlines when he describes Anna Deavere Smith's process of composing and performing Fires in the Mirror: "as a ritual shaman might investigate and heal and diseased or possessed patient" (1993:64). By "patient," I assume he means the society that gives rise to such violence, not the victims per se. However, with the public discourse following the massacres revolving so completely around identification with the victims, it's easy enough to see how the personal conscience might elide the social. There is also a tinge of (unintended) condescension: the outsider-artists, stepping into the site of injury, staging an idea(l) of the social by channelling the voices of the victims and producing a performance of healing for audiences well beyond the locus of the event. Above all, I wonder: how is it that no one imagines the victims themselves as artists, or at least sufficiently fluent in the 
arts, as such capable of creating aesthetic responses to the situation in which they have found themselves?

\section{Kia kaha / kia haka ${ }^{18}$}

In instating the imaginary of a multicultural nation, the Prime Minister's "they are us" created a new sort of binary in which Pākehā New Zealanders retained dominance and the Other was redefined, temporarily, as Muslim instead of Māori as is otherwise customary. But Māori performance - primarily the haka ${ }^{19}$ - was everywhere in the days and weeks following the event. Almost every newscast contained a video clip of a school group performing in front of one or the other of the mosques. The students had lost friends, and their friends had lost family members; the tragedy cut deeply through the lives of young people in this way (see, for example: Roes 2019; NZ Herald 2019b; Francis 2019). At the other end of the spectrum, members of Black Power, one of New Zealand's notorious gangs, also felt compelled to convey their respects with haka outside the mosque (NZ Herald 2019a). Most moving, I think, was the haka performed by a solitary man outside the mosque in the darkness the next evening. Rough staff in hand, he paces and chants, puts his râkau (wooden staff) on the pavement and launches into a full rendition of "Ka Mate":

Ka mate! Ka mate! Ka ora! Ka ora!

Ka mate! Ka mate! Ka ora! Ka ora!

Tēnei te tangata pūhuruhuru

Nāna nei I tiki mai whakawhiti te rā

$\bar{A}$, upane! Ka upane!

$\overline{\mathrm{A}}$, upane! Ka upane! Whiti te rā!20

\footnotetext{
${ }^{18}$ Stay strong / stay dancing.

19 The haka is a ritual performance practice that combines dance and song, generally performed by men (or with men in the lead). It is most often understood as a "war dance" because of its attachment to the All Blacks, however it is performed in a wide range of contexts. By itself, the word "haka" means simple dance or performance.

20 "I die! I die! I live! I live! / I die! I die! I live! I live! / This is the hairy man / Who fetched the Sun / And caused it to shine again / One upward step! Another upward step! / An upward step, another, the
} 
He finishes, standing upright, breathing heavily, his right hand arced in front of his body in a wiri (quivering gesture). After a pause, he picks up his stick, draws a line on the concrete towards the onlookers, then walks away to rejoin the vigil (Washington Post 2019). There's no "they are us" in this haka. Facing violence and death, it holds the ground against despair. It calls to ancestors, calls to the living and calls to those yet to be born. It is part of history, and it is beyond history. It belongs to this place in the way that most of us do not, and instead of pushing us away, it welcomes us, offers us a home while reminding us of the inevitability of our passing.

In all the shock talk, the dismay at finding ourselves - those of us who were neither Muslim nor Māori - not so distant as we believed from the violence of white nationalism and moved by our desire to be somehow not that, it was too easy perhaps to step to one side of the history of colonization. The haka put us all back into place without effacing the past. The peace had, once again, been broken by violence. Performed in the street, the haka honoured the dead and the living together. Even more than the prayers on the platform, more than the Prime Minister's press conferences and embraces, more than the scarves of solidarity, these haka were performances of repair, acts of faith in a transcendent humanity set within an all too temporal reality.

\section{And now?}

Commemorative services are planned for the first anniversary, which is fast-approaching. The eyes of the nation and the world are no longer so transfixed on New Zealand's Muslim community. There have been other tragic events in the interim, here as elsewhere. ${ }^{21}$ Stories

Sun shines!" (Kāretu 1993). For a discussion of the origins of this iconic haka by its people, see the Ngāti Toa Rangatira website.

${ }^{21}$ Most notably, in December, a volcano violently erupted on White

Island; twenty have died from burns, 23 remain in hospital, some still 
still surface regularly, mostly revealing the way the victims and their families have struggled to navigate the gaps between the government's good intentions and its bureaucratic processes - largely due to lapses in the empathetic imaginations of officials, it seems, a "rules is rules" approach that itself implies that the playing field is as level for "them" as for "us." The tension is especially acute for those who are on temporary visas, the almost "us" (Vui-Talitu 2019). The question of who actually can be designated a "victim" - only those struck by bullets and their immediate families? those who were in the mosques but physically uninjured? - in order to receive bureaucratic, financial and other forms of support remains only partially resolved. Having been initially scheduled to start in May during Ramadan, which would have made attendance difficult for those most directly affected, the trial - a much-anticipated performance of justice - has been pushed to June 2020 (Gay \& Sherwood 2019). Perhaps now, in the lull before the next social storm, it might be time enough to consider who, what "we" have become as a result of the violence against "them" and how we might come to perform as "us."

\section{References}

critically injured, and two bodies were never found (Perper and Esfandiari 2020). 
1news. 2018. "Taika Waititi says New Zealand 'the best place on the planet', but 'racist as $\mathrm{f}^{* * *}$ ' in latest interview." 1news (9 April). Accessed 8 September 2019.

https://www.tvnz.co.nz/onenews/entertainment/taika-waititi-says-new-zealandbest-place-planet-but-racist-f-in-latest-interview.

Ahmed, Sara. 2000. Strange Encounters: Embodied Others in Post-Coloniality. London \& New York: Routledge.

Anderson, Benedict. (1983) 2006. Imagined Communities: Reflections on the Origin and Spread of Nationalism. London \& New York: Verso.

Baudrillard, Jean. (1990) 1993. The Transparency of Evil: Essays on Extreme Phenomena, translated by James Benedict. London \& New York: Verso.

Berlant, Lauren, ed. 2004. Compassion: The Culture and Politics of an Emotion. New York: Routledge.

Connolly, Kate. 2019. "All Germans urged to wear kippah in protest against antisemitism." The Guardian (31 May). Accessed 10 September 2019. https://www.theguardian.com/world/2019/may/31 /germans-urged-wear-kippah-protest-antisemitism.

Dabashi, Hamid. 2014. "Gaza: Poetry after Auschwitz." Al-Jazeera (8 August). Accessed 10 January 2020. https://www.aljazeera.com/indepth/opinion/2014/0 8/gaza-poetry-after-auschwitz201487153418967371.html.

Diamond, Elin. 1992. "The Violence of 'We': Politicizing Identification." In Critical Theory and Performance, edited by Janelle Reinelt and Joseph Roach, 390-398. Ann Arbor, MI: University of Michigan Press.

Dolan, Jill. 2005. Utopia in Performance: Finding Hope at the Theater. Ann Arbor: The University of Michigan Press.

Feek, Belinda. 2019. "Headscarf for Harmony about 'showing solidarity' with Muslim women in NZ." $N Z$ Herald (21 March). Accessed 8 September 2019. https://www.nzherald.co.nz/nz/news/article.cfm?c_i d=1\&objectid=12214920. 
Francis, Ben. 2019. "NRL 2019: Warriors perform haka at Masjid Al Noor mosque." Newshub (30 March). Accessed $19 \quad$ September 2019. https://www.newshub.co.nz/home/sport/2019/03/ nrl-2019-warriors-perform-haka-at-masjid-al-noormosque.html.

Gay, Edward, and Sam Sherwood. 2019. "Christchurch mosque shooting trial delayed for Ramadan." Stuff.co.nz (12 September). Accessed 15 January 2020.

https://www.stuff.co.nz/national/crime/115747194 /christchurch-mosque-shooter-trial-delayed-forramadan.

Helmore, Edward. 2019. "Anger as grinning Trump gives thumbs-up while Melania holds El Paso orphan." The Guardian (9 August). Accessed 15 September 2019. https://www.theguardian.com/usnews/2019/aug/09/trump-el-paso-melania-orphanbaby-thumbs-up.

Hood, Lynley. 2001. A City Possessed: The Christchurch Civic Creche Case - Child Abuse, Gender Politics and the Law. Dunedin: Longacre Press.

Kāretu, Tìmoti. 1993. Haka! The Dance of a Noble People. Auckland: Reed.

Kightley, Oscar. 2019. "After the Christchurch shootings, we must root out the racists who walk among us." Stuff (17 March). Accessed 8 September 2019. https://www.stuff.co.nz/national/111332125/wemust-root-out-the-racists-who-walk-among-us.

Knausgaard, Karl Ove. (2011) 2018. The End: My Struggle 6 , translated by Martin Aitken and Don Bartlett. London: Vintage.

Luscombe, Belinda. 2020. "A Year After Christchurch, Jacinda Ardern Has the World's Attention. How Will She Use It?" (20 February 2020). Accessed 22 February 2020. https://time.com/5787443/jacindaardern-christchurch-new-zealand-anniversary $/$. 
Maalouf, Amin. (1996) 2012. In the Name of Identity: Violence and the Need to Belong, translated by Barbara Bray. New York: Arcade Publishing.

Malik, Nesrine. 2019. "With respect: how Jacinda Ardern showed the world what a leader should be." The Guardian (28 March). Accessed 10 September 2019. https://www.theguardian.com/world/2019/mar/28 /with-respect-how-jacinda-ardern-showed-the-worldwhat-a-leader-should-be.

Mazer, Sharon. 2011.

Ethnographer/Tourist/Cannibal."

"Performance:

Drama Studies 59: 104-120.

Mazer, Sharon, ed. 2013. "Reflections on Theatre and Performance in the (Post-) Earthquake Zone." Australasian Drama Studies 62 (June): 68-88.

Mazer, Sharon. 2015. "Quake City." Performance Research 20, 3 (June): 163-172.

Nash, Stuart. 2019. "Gun buyback over, next phase underway." Beehive.govt.nz (21 December). Accessed 10 January 2020. https://www.beehive.govt.nz/release/gun-buybackover-next-phase-underway.

Neiman, Susan. 2019. "Working off the Past, from Atlanta to Berlin." NYR Daily / New York Review of Books (1 September). Accessed 10 January 2020. https://www.nybooks.com/daily/2019/08/26/worki ng-off-the-past-from-atlanta-toberlin/?utm_medium=email\&utm_campaign=NYR.

Ngāti Toa Rangatira. n.d. "The Origins of Ka Mate". Accessed 12 January 2020. http:/ / www.ngatitoa.iwi.nz/ka-mate/the-origins-ofka-mate.

NZ Human Rights Commission. 2017. "Give Nothing To Racism." YouTube (15 June) https://www.youtube.com/watch?v=g9n_UPyVR5s.

Nichols, Bill. 2007. "The Terrorist Event." In Ritual and Event: Interdisciplinary Perspectives, edited by Mark Franko, 93-108. London \& New York: Routledge. 
NZ Herald. 2019a. "Black Power perform haka outside Al Noor Mosque cordon in Christchurch." NZ Herald (17 March). Accessed 19 September 2019. https://www.nzherald.co.nz/nz/news/article.cfm?c_i d=1\&objectid=12213564.

NZ Herald. 2019b. "Mass haka and waiata performed outside Christchurch mosque to honour shooting victims." NZ Herald (21 March). Accessed 19 September 2019. https://www.nzherald.co.nz/nz/news/article.cfm?c_i $\mathrm{d}=1 \&$ objectid=12214811.

NZ Herald. 2019c. "National Remembrance Service for victims of Christchurch terrorist attack." NZ Herald (29 March). Accessed 8 September 2019. https://www.nzherald.co.nz/nz/news/article.cfm?c_i $\mathrm{d}=1$ \&objectid=12217364.

NZ Herald. 2019d. "What Jacinda Ardern wrote in the minutes after the mosque terror attacks revealed." $N Z$ Herald (6 April). Accessed 8 September 2019. https://www.nzherald.co.nz/nz/news/article.cfm?c_i $\mathrm{d}=1$ \&objectid=12219986.

Pacific at AUT. 2019. "Light \& Love: An Expression of Peace." Facebook. Accessed 10 January 2020. https://www.facebook.com/autpacific/videos/78816 6988226548/.

Perper, Rosie \& Sahar Esfandiari. 2020. "Death toll from New Zealand volcano rises to 20, with 2 bodies still missing." Insider (13 January). Accessed 15 January 2020. https://www.insider.com/whakaari-whiteisland-volcano-eruption-new-zealand-photos-videosinjuries-2019-12.

"Population and demographics." Christchurch City Council. Accessed 10 January 2020. https://www.ccc.govt.nz/culture-andcommunity/christchurch/statistics-and-facts/factsstats-and-figures / population-and-demographics/.

RNZ. 2019a. "Christchurch mosque shootings: "This can only be described as a terrorist attack' - PM Jacinda Ardern." RNZ (15 March). Accessed 15 September 
2019.

https://www.rnz.co.nz/news/national/384803/chris tchurch-mosque-shootings-this-can-only-bedescribed-as-a-terrorist-attack-pm-jacinda-ardern.

RNZ. 2019b. "Thousands attend vigils to remember mosque shooting victims." RNZ (22 March). Accessed 15 September 2019. https://www.rnz.co.nz/news/national/385351/thou sands-attend-vigils-to-remember-mosque-shootingvictims.

Roes, Kawe. 2019. "Māori way of expressing love': Haka used to express grief after Christchurch attack." Stuff.co.nz (20 March). Accessed 19 September 2019. https://www.stuff.co.nz/national/christchurchshooting/111420740/mori-way-of-expressing-lovehaka-used-to-express-grief-after-christchurchshootings.

Roy, Eleanor Ainge. 2019. "Real leaders do exist': Jacinda Ardern uses solace and steel to guide a broken nation." The Guardian (19 March). Accessed 8 September 2019. https://www.theguardian.com/world/2019/mar/19 Lreal-leaders-do-exist-jacinda-ardern-uses-solaceand-steel-to-guide-a-broken-nation.

Russell, Emma. 2019. "Muslim sisters distraught after being verbally abused at Mt Albert train station." NZ Herald (17 March). Accessed 8 September 2019. https://www.nzherald.co.nz/nz/news/article.cfm?c_i $\mathrm{d}=1$ \&objectid=12213536.

Salmond, Anne. 2019. "Dame Anne Salmond: Racist underbelly seethes just beneath surface." NZ Herald (19 March). Accessed 8 September 2019. https://www.nzherald.co.nz/nz/news/article.cfm?c_i $\mathrm{d}=1$ \&objectid=12213747.

Schechner, Richard. 1993. "Anna Deavere Smith: Acting as Incorporation." TDR/The Drama Review 34, 4 (T140): 63-64.

The Associated Press. 2018. "Over 2,000 Attend "Wear a Kippa' Protest in Berlin After anti-Semitic Attack." Haaretz (25 April). Accessed 10 September 2019. 
https://www.haaretz.com/worldnews/europe/berlin-jews-organize-wear-a-kippahdemonstration-in-response-1.6026552.

Thornber, Lorna. 2018. "Godzone: Is New Zealand really heaven on Earth?" Stuff (18 September). Accessed 5 January 2020. https://www.stuff.co.nz/travel/destinations/nz/107 $175922 /$ godzone-is-new-zealand-really-heaven-onearth.

Vui-Talitu, Sara. 2019. "Two mosque attack widows plea for residency." Stuff.co.nz (14 October). Accessed 10 January 2020. https://www.stuff.co.nz/national/116575781/twomosque-attack-widows-plea-for-residency.

Waka Toa Ora. n.d. "A demographic profile of Christchurch." Healthy Christchurch. Accessed 10 January 2020. https://www.healthychristchurch.org.nz/city-healthprofile/who-lives-here.

Washington Post. 2019. "Man performs haka outside of New Zealand mosque." Washington Post (18 March). Accessed $10 \quad$ January 2020. https://www.washingtonpost.com/video/world/man -performs-haka-outside-of-new-zealandmosque/2019/03/17/548863c1-3008-4dbe-8b09ad7f37568e00_video.html.

Webb-Liddal, Alice and Scott Palmer. 2019. "Scarves in Solidarity urges Kiwis to wear scarves on Friday." Newshub (20 March). Accessed on 8 September 2019. https://www.newshub.co.nz/home/newzealand/2019/03/scarves-in-solidarity-urges-kiwisto-wear-scarves-on-friday.html. 